\title{
Turkish Foreign Policy in a Changing World Order
}

\author{
H. Tarık Oğuzlu \\ Antalya Bilim University
}

\begin{abstract}
This article argues that there is a close relationship between the structure of the international system/order and how states define their foreign policy interests and then act accordingly. The main contention is that Turkey's foreign policy performance since 2002 can be partially read as Turkey's effort to adapt to external developments at international and regional levels. As the international system has evolved from a unipolar order (in which the United States, in cooperation with its European allies, provided the main public goods in an hegemonic fashion), into a post-unipolar era, Turkey has accelerated its efforts to pursue a more multi-dimensional and multi-directional foreign approach. Rather than arguing that there is a direct causation between the independent variable of systemic factors and the dependent variable of Turkey's foreign policy performance, this article understands the external environment as a 'context' in which Turkish decision makers have responded to Turkey's responses to foreign policy developments.
\end{abstract}

Keywords: Turkish foreign policy, international system, liberal international order, Middle East, rising powers

\section{Introduction}

There is a relationship between the structures of the international system/order and how states define their foreign policy interests and then act accordingly. Turkey's foreign policy performance since 2002, when the ruling Justice and Development Party (AK Party) came to power, can be partially read as Turkey's efforts to adapt to the external developments taking place at international and regional levels. Despite the fact that foreign policy is generally informed by a combination of internal and external factors, this article underlines the importance of the latter.

The goal here is not to explain and demonstrate Turkey's foreign policy as an outcome of external factors in the sense of causality. Instead, the goal is to underline the importance of the external environment as a 'set of constraints and opportunities', which has not only helped the ruling elites fulfill their domestic political agenda, particularly during the first decade of the twenty-first century, but has also had a role in forming the preferences and behaviours of Turkey's foreign policy.

The political calculations of the ruling AK Party governments, particularly in civil-military relations, the geopolitical imaginations of the ruling elites, consecutive electoral victories of the ruling party, and the strong leadership of then Prime Minister Erdogan, have influenced

H. Tarık Oğuzlu, Professor, Political Science and International Relations Department, Antalya Bilim University. Email: tarik.oguzlu@antalya.edu.tr. (D) https://orcid.org/0000-0002-5422-6203 
how Turkey interprets the external developments taking place at regional and systemic levels. Therefore, it would not be wrong to ask whether Turkey's foreign policy preferences and behaviors would have been different had another political party ruled Turkey during this period, for instance the Republican People Party. A neo-classical realist would likely say that Turkey's interpretation of the external environment during the time period under consideration would have been different, mainly because these two political parties adopted different political values and geopolitical imaginations. Nevertheless, this is a hypothetical question and requires sophisticated speculation. Even though unit level variables have played a role in shaping Turkey's responses to external stimuli over the last sixteen years, as the proponents of neo-classical realism claim $^{1}$, this article does not aim to show how these unit level variables have been factored into the ruling elites' interpretation of the external factors.

On the other hand, the major difficulty limiting the explanatory power of structural realism in this study is that Turkey's foreign policy preferences since 2002 seem to have been informed by both systemic and internal factors simultaneously. The fact that Turkey's responses to external developments during this period seem to have strongly reflected the political calculations of the ruling AK Party governments dilutes the explanatory weight of structural realism. The difficulty in differentiating the impact of systemic/external factors from the impact of unit-level factors is a major constraint, mainly because both appear to have expected the same foreign policy preferences to be adopted.

Against this background, this article does not argue that there is a direct causation between the independent variable of systemic factors, and the dependent variable of Turkey's foreign policy choices and behaviors. The goal is to modestly demonstrate how Turkey's responses to the external developments at regional and systemic levels have largely agreed with structural realist expectations. Although the reality of the external environment is filtered through decision makers in reference to their political calculations, worldviews, and foreign policy visions ${ }^{2}$ this article argues that Turkey's foreign policy performance over the last sixteen years appears to have vindicated structural realist expectations. Turkey's foreign policy choices have closely varied with the changing dynamics of polarity at systemic and regional levels, as well as with evolving views on the legitimacy of the US-led liberal international order.

Turkey's foreign policy before the global financial crisis in 2008 reveals that Turkey's choices almost always accorded with structural realist expectations. Turkey followed a prowestern/pro-European foreign policy, particularly in the Middle East, not only because this suited the political calculations of the ruling elites, but also because the strong legitimacy of the US-led liberal international order (as well as a power imbalance in favor of western powers) did not allow Turkey any other credible choice. A neo-classical realist would theoretically argue that the internal political calculations of the ruling AK Party, particularly as regards its legitimacy needs against diehard skeptics in the military and secular opposition, have led AK Party elites to interpret the constitutive norms of the US-led western international order order legitimate and pave the way for a pro-western Turkish foreign policy. This does not change that the way Turkish foreign policy unfolded during this era accorded well with the strategic interests of western powers, particularly in the Middle East.

Steven E. Lobell, Norin M. Ripsman and Jeffrey W. Taliaferro, eds., Neoclasical Realism, the State and Foreign Policy (Cambridge: Cambridge University Press, 2009).

2 Gideon Rose, "Neoclassical Realism and Theories of Foreign Policy," World Politics 51, no. 1 (1998): 144-72, https://doi. org/10.1017/S0043887100007814; Brian Rathbun, "A Rose by Any Other Name: Neoclassical Realism as the Logical and Necessary Extension of Structural Realism,” Security Studies 17, no. 2 ( 2008): 294-321, https://doi.org/10.1080/09636410802098917. 
Structural realism holds that as the international order shifts from unipolarity to multipolarity, the maneuvering capability of states, particularly middle and small powers, increases. Transition times offer countries more opportunities in their foreign policies. As the primacy of an existing global hegemon is disputed by rising potential hegemons globally, the maneuvering capability of regional powers like Turkey increases. The Obama administration's strategies of 'retrenchment' and 'nation-building at home' should be seen as external developments which strengthen Turkey's foreign policy agency. The internal crises within the EU and the gradual rise of non-western powers, particularly China and Russia, seem to have contributed to the power vacuum at systemic and regional levels. Turkey has certainly taken advantage of this in its foreign policy. This is why Turkey could easily adopt an 'order constituter role' in the Middle East during the developments associated with the so-called Arab Spring.

The Russian military involvement in Syria in late 2015, the election of Donald Trump to US presidency in late 2016, Trump's continuing efforts to undo the legacy of Obama, the increasing penetration of China into the Middle Eastern theater, the growing geopolitical rivalry between Shi'a and Sunni power blocks, and Turkey's worsening security situation at home have caused a realist revival in Turkish foreign policy over the last three years. This also suggests that Turkey's maneuvering capability in the Middle East has steadily decreased, as other regional and non-regional powers have increased their efforts to shape the course of developments on the ground in their favor. Within this time period, and in the context of the continuous decline of western-world primacy in global politics, Turkey put more effort into forging cordial relations with rising non-western powers.

Some caveats are in order though. First, this essay does not offer a detailed and comprehensive analysis of Turkish foreign policy as it has evolved since 2002. For a detailed explanation of the core issues occupying Turkey's foreign policy agenda, readers would do well to resort to other sources. Second, the main focus is on Turkey's Middle East policy; developments in this region, rather than others, have decisively affected Turkey's foreign policy interests and behaviors. Third, this essay does not engage in a theory application exercise that tests the major assumptions of structural realism or neo-classical realism in light of Turkey's foreign policy. Rather, the goal is to offer a modest explanation of how changes in the structure of international order over the last sixteen years might be reflected in the evolution of Turkish foreign policy.

What follows is a short description of the changes occurring in the structure of the international system, in the context of material and normative dimensions. Whether the international order evinces the features of unipolarity, bipolarity, or multipolarity would be bound to have an impact on how states shape their foreign policy interests and behaviors. The article will then focus on the changes in Turkey's foreign policy performance since 2002 until now. I will divide the time period under consideration into three; the first covers the years between 2002 and 2008, the second between 2008 and 2015, and the third covers the last three years. During each period, Turkey's foreign policy record shows some notable differences, in sync with changes observed in the structure of international order.

\section{The Changing World Order}

Since the early years of the twenty-first century, the center of gravity of international politics has gradually shifted from the Transatlantic region to the Pacific/Indo-Pacific region. As the 
primacy of western actors in international politics has come under strong challenges from the growing power capabilities of non-western powers, most notably China, they have also contested the ideational and normative underpinnings of the US-led liberal international order. The world is now going through a transformation process; 'Pax-Americana' is gradually giving way to a post-American world order in which a group of non-western countries are becoming more influential than ever in shaping the course of international developments. ${ }^{3}$ This transformation seems to have accelerated since the financial crisis in 2008, which primarily affected the United States and many EU members.

Since the early 1990s and until 2008, the United States, in partnership with its European allies within NATO and the European Union, dictated international politics. This period was the heyday of the 'liberal international order'. Not only did it gradually expand to include former communist countries in central and Eastern Europe, but also the immense material power capabilities of the United States allowed her to pursue primacist strategies all around the world. The occupation of Iraq in 2003, and the United States' military involvement in Afghanistan in the aftermath of the September 11 (9/11) attacks, epitomized the excessive self-confidence of American decision makers in promoting liberal democratic order. ${ }^{4}$ Until 2008, the rise of China was not central to American strategic considerations and the European Union was at the apex of its power. The security strategy concepts of Americans and European alike demonstrated the exuberance, optimism, and self-confidence in western capitals. Neither the national security strategies adopted by the George W. Bush and Obama administrations in the US, nor the first-ever security strategy document of the EU adopted in 2003, mentioned great power competition and ideological polarization as potential threats to liberal international world order. ${ }^{5}$ Many circles in the West took comfort in Fukuyama's thesis that the history came to an end with the dissolution of the Soviet Union, and with the growing appeal of liberal-capitalist democracy as the only game in town.

Even though the 9/11 attacks on the US homeland dented the image of the United States as the omnipotent global hegemon, and criticisms of the American approach to the global war on terror intensified following the US occupation of Iraq, it was primarily following the financial crisis of the late 2000s that a sense of decline began to percolate down to the western elites in the United States and members of the EU. Not only has the feeling of optimism eroded, but also the specter of non-western powers challenging the primacy of western powers has begun to haunt many westerners. As the Russian resurgence and Chinese revival took root, the calls for accommodating rising non-western powers in the institutional structure of the liberal international order began to be heard more loudly. The revised security strategy of the European Union (issued in the summer of the 2016), and the first national security strategy of the Trump administration (issued in December 2017) demonstrate that western powers feel threatened by the rise of non-western powers. Both documents suggest some ways to deal with the resurgence of concerns for traditional security, as well as the worldwide emergence of illiberal authoritarianism. ${ }^{6}$

\footnotetext{
3 G. John Ikenberry, "The Plot against American Foreign Policy: Can the Liberal Order Survive?," Foreign Affairs 96, no. 3 (2017): 2-9, https://www.foreignaffairs.com/articles/united-states/2017-04-17/plot-against-american-foreign-policy.

4 Constance Duncombe and Tim Dunne, "After Liberal World Order," International Affairs 94, no. 1 (2018): 25-42.

5 "The National Security Strategy of the United States of America," September 2002, https://www.state.gov/documents/ organization/63562.pdf; and "National Security Strategy," May 2010, http://nssarchive.us/national-security-strategy-2010/; "European Security Strategy, A Secure Europe in a Better World," December 2003, https://europa.eu/globalstrategy/en/europeansecurity-strategy-secure-europe-better-world. 
Since 2008, there have been disputes all over the world over the values of multiculturalism, openness, tolerance, and universal human rights. The morality of universal cosmopolitanism has gradually given way to the morality of relative communitarianism as rising non-western powers, primarily China and Russia, have increasingly offered non-western conceptualizations of international political order. Non-interference in states' internal affairs, primacy of state sovereignty, authoritarian leadership, the strengthening of national identities, state-led capitalism, spheres of influence mentality, multipolarism in global governance, primacy of great powers in international relations, mercantilist trade practices, investment in military power capabilities, an increased use of economic power instruments in the name of securing geopolitical gains, and the questioning of the principle 'responsibility to protect' are some of the points that Russian and Chinese leaderships have been vehemently prioritizing over the last decade. ${ }^{7}$ This does not suggest that countries like China have not benefited from the liberal international order, particularly in the field of economics. However, China's gains from the liberal-capitalist global order mainly emanate from western sponsorship, rather than from China acting as a convicted disciple. So long as the western powers, particularly the United States, assumed that China would turn out to become a responsible stakeholder and gradually transform into a liberal democratic polity, they tolerated China's rise and its inappropriate trade practices and non-democratic political values. The West was able to endure some economic losses relative to emerging powers, so long as it had self-confidence.

The western powers have not been immune to such currents either. The last decade has witnessed the rise of populist and illiberal political movements in key western countries. The internal criticism of liberal democratic practices has severely affected the attractiveness of a liberal world order. ${ }^{8}$ As the Brexit decision in the United Kingdom and the election of Donald Trump to presidency in the United States demonstrates, the forces of illiberalism, populism, protectionism, and xenophobia have gained ground in key western countries.

Parallel to the shift in material power capabilities across the globe and the growing challenges posed to the normative foundation of the liberal international order, realpolitik foreign policy practices and pragmatic concerns in defining national interests have become more pronounced than moralpolitik practices and normative concerns. Power politics and 'sphere of influence' mentality have experienced a revival over the last decade. As geo-economic and geo-political motivations have become more decisive in states' foreign policies, the dynamics of alliance relationships have also gone through a radical transformation. During the last decade, long-term identity based alliance relationships have been replaced with short-term, pragmatic, and issue-oriented strategic partnerships. ${ }^{9}$ The practice of forming interest-oriented cooperation initiatives within multilateral and bilateral frameworks has gained ground in recent years. In today's world, countries of different value orientations, geographical locations, power capabilities, and threat perceptions are no longer bound to define each other categorically as enemies or friends. The notion of 'frenemy' has

uploads/2017/12/NSS-Final-12-18-2017-0905.pdf; and "European Union Global Strategy, Shared Vision, Common Action: A Stronger Europe A Global Strategy for the European Union's Foreign And Security Policy,” June 2016, https://eeas.europa.eu/ archives/docs/top_stories/pdf/eugs_review_web.pdf.

Alexander Lukin, "Russia in a Post-Bipolar World," Survival 58, no. 1 (2016): 91-112, doi: 10.1080/00396338.2016.1142141; and François Godement, "Expanded Ambitions, Shrinking Achievements: How China sees the global order," (Policy Brief, March 2017, European Council on Foreign Relations, London, UK), http://www.ecfr.eu/publications/summary/expanded_ambitions_ shrinking_achievements_how_china_sees_the_global_order.

8 Michael J. Boyle, "The Coming Illiberal Order," Survival 58, no. 2 (2016): 35-66.

9 Thomas S. Wilkins, “'Alignment', not 'Alliance'- The Shifting Paradigm of International Security Cooperation: Toward a Conceptual Taxonomy of Alignment," Review of International Studies 38, no. 1 (2012): 53-76. 
already become an identity signifier in interstate relations. The practice of coalitions defining missions has gradually given way to the practice of missions defining coalitions. As opposed to Cold War bipolarity, and the unipolar order during the first two decades of the post-Cold War era, the practice of illiberal authoritarian states engaging in pragmatic outcome-oriented cooperation with liberal-minded states is now conceivable.

In today's international order, the ideological polarization of opposing power blocks is not as sharp and rigid as it was during the Cold War era. The interconnectedness between liberal western powers and illiberal authoritarian powers is much higher now than it was between western capitalist and eastern communist countries during the Cold war era. This suggests that we now live in a multiplex world order. ${ }^{10}$ Not only are there more actors in international relations, but also the issues have become so complex that dealing with them increasingly requires global perspectives. This world order leads states with various power capabilities to adopt multidimensional and multidirectional foreign policy strategies; aligning a particular group of countries against others in a long-term structural manner is no longer an option.

Even though the debate on the decline of the West still lingers, and many question the idea of declinism in the United States, ${ }^{11}$ it is now clear that the United States, under Trump's presidency, no longer wants to play the leader of the liberal international order. This creates enough room for non-western rising powers to act more assertively and become more visible across the globe.

\section{Pro-Western Realism in Turkish Foreign Policy, 2002-2008}

During the first decade of the AK Party rule, Turkey adopted a pro-western, pro-European stance in its foreign policy, for strategic reasons, with more engagement in non-western environments, particularly the Middle East. Not only was Turkey highly committed to joining the EU, but also it increasingly showed its desire to support the promotion of western values to non-western geographies. Turkey's 'EUropean' foreign policy in the Middle East is a testament to how attractive the liberal international world order is in the eyes of Turkish decision makers. ${ }^{12}$ Its willingness to take part in the US-led Greater Middle Eastern Initiative also suggests that a key foreign policy interest of Ankara was to transform the Middle East to reflect liberal democratic values.

Leaving aside the internal motivations of the AK Party politicians to accelerate the national Europeanization process, Turkey's perception of international order was that Western primacy in international relations was second to none, despite all counter challenges. Given the unipolar world order, Turkish rulers assumed that adopting the liberal democratic values of the western international community would provide the most appropriate solutions to Turkey's structural economic, social, and political problems. In parallel to increasing Europeanization and democratization efforts at home, Turkey was seen by western powers as a successful role model for countries in the greater Middle Eastern region. The transformation of the Hobbesian security environment in the Middle East into a Kantian one was considered to be vital to Turkey's efforts to successfully complete its economic development process, as well as maintain its territorial integrity and societal cohesion.

${ }_{10}$ Amitav Acharya, "The Future of Global Governance: Fragmentation May Be Inevitable and Creative," Global Governance 22 (2016): 453-60.

11 Barry R. Posen, "The Rise of Illiberal Hegemony," Foreign Affairs, February 2018, http://www.foreignaffairs.com/ articles/2018-02-13/rise-illiberal-hegemony.

12 Tarik Oguzlu, "Turkey and Europeanization of Foreign Policy," Political Science Quarterly 125, no. 4 (2010-2011): 657-83. 
During this time period, Turkey's Middle Eastern policies were undoubtedly European in nature. Similar to China's peaceful rise and development policy in East and South East Asia, Turkey wanted to help transform its near abroad, ensuring that regional developments did not hamper Turkey's internal transformation process. The instruments of Turkish foreign policy, the style of decision-making process, and the content of foreign policy choices adopted in regional issues sounded very European. Turkey pursued a realist foreign policy with a liberal tool kit. Despite the fact that the 'strategic depth' doctrine and the 'zero problems with neighbors' foreign policy mantra of the ruling elites were considered by some to be Turkey's efforts to pursue a neo-Ottomanist agenda in an imperial fashion, during this era Turkish foreign policy was everything but imperial. Turkey's engagement in thr Middle East was inspired by a strategic motivation to transform the region into a stable and secure environment with European values and practices so that Turkey itself did not feel threatened. Working to alleviate perennial security problems with neighbors to the south, particularly Syria and Iran, and helping to create an EU-like regional integration process, were among the main pillars of Turkey's regional policies in Middle East. ${ }^{13}$ The fact that non-democratic and authoritarian nature of the political regimes of Turkey's Middle Eastern neighbors had not prevented Turkish decision makers from developing cordial and functional relationships with them can be seen as an indication that, during this era, Turkey embraced a realist foreign policy.

As a long time member of the western international community, Turkey's goal was not to spoil the existing liberal international order. Despite the fact that Turkey, similar to many other rising powers, felt that the current order was unjust and favored the primacy of western powers, Turkish rulers had not radically overhauled the concept of the liberal international order in their foreign policy. Turkey was quite satisfied with the liberal democratic values of the order; however, it wanted non-western powers to have more voice and better representation in existing international institutions so that the international order was a better reflection of the current distribution of material power capabilities.

Despite Turkish rulers paying a great amount of attention to improving relations with Russia and coming closer to China, one can hardly say that there were a lot of people arguing in favor of an Eurasian-centered stance in Turkey's international orientation. Though Turkey's response to the Russian invasion of Georgia in the summer of 2008 was much milder than that of the United States and many EU members, Turkey felt uneasy with Russia's use of brute force in dictating its terms to neighboring countries. Ankara did not perceive that the Russian challenge to the post-modern security order in the European continent was positive. ${ }^{14}$

\section{Liberal Optimism in a Search for Strategic Autonomy, 2008-2015}

Following the second electoral victory in the parliamentary elections of the summer of 2007 , and the election of Abdullah Gul to presidency despite all counter efforts, AK Party rulers felt self-confident enough to set an identity-based transformation process in motion at home and in relations with external actors. This coincided with the gradual deterioration of Turkey's relations with western actors, and the steady decline of western primacy in global politics

\footnotetext{
13 Bülent Aras and Rabia Karakaya Polat, "From Conflict to Cooperation: Desecuritization of Turkey's Relations with Syria and Iran," Security Dialogue 39, no. 5 (2008): 495-515.

${ }^{14}$ Ziya Oniş and Şuhnaz Yılmaz, "Turkey and Russia in a Shifting Global Order: Cooperation, conflict and asymmetric interdependence in a turbulent region," Third World Quarterly 37, no. 1 (2016): 71-95.
} 
following the 2008 global financial crisis. As a result of cooling relations with the EU and growing differences with the US, Turkey began a continuous search for strategic autonomy. The onset of accession negotiations with the EU in 2005 did not set Turkey on an irreversible European path. Growing European opposition to Turkey's prospective EU membership (on the grounds of ideational and normative factors) seems to have been reciprocated by a dwindling Turkish determination to fulfill the membership criteria. The economic crisis in Europe made EU membership even less attractive. ${ }^{15}$ Deteriorating relations with the US, mostly in the context of diverging strategic priorities in the Middle East, further eroded the western dimension in Turkish foreign policy. ${ }^{16}$

In the years between 2008 and 2015, there were strong normative and moral considerations in Turkish foreign policy practices, particularly in the Middle East. Amid the revolutionary changes taking place in the Middle East in the context of the so-called Arab Spring, Turkey began to pursue a transformational regional policy; Turkish decision makers appear to have believed that Turkey's hour had finally arrived. ${ }^{17}$ Since the onset of revolutions across the region until the middle of 2015, Turkey's number one foreign policy goal was to bring about a new regional order, with Turkey playing a leading role in strengthening representative democracy and regionalism. Playing a lead role was in line with Turkey's determination to help erase the imprint of external actors in the region, and replace it with new power blocks that would align their interests with an AK Party-ruled Turkey.

During this time, it became clear that the gap between Turkey's ends and means was too difficult to bridge in the short-term. Despite warning calls that Turkey would likely suffer from a gap between its expectations and capabilities, particularly in Syria, AK Party rulers ignored them and continued to believe that Turkey was on the right side of history. The assumption was that Turkey would eventually benefit from its moral position in the region, no matter which developments might temporarily alienate the country. After all, the alleged loneliness would be precious. ${ }^{18}$

The quest for strategic autonomy was mainly informed and aided by the retrenchment policies of the US under Obama, as well as the increasing failure of the European Union to craft a convincing approach towards the Middle East in the midst of its structural problems at home.

The determination of the Obama administration to scale down the American presence in the Middle East (by gradually withdrawing US soldiers from Afghanistan and Iraq), and stay away from the internal war in Syria, seems to have motivated Turkey to play a more assertive role in the region. ${ }^{19}$ Following the economic crisis in 2008, both the US and EU members began to focus their energy and capital on fixing economic and social problems at home, while decreasing their external engagement in nation-building and democracy-promotion activities abroad. President Obama's 'leading from behind' strategies in war zones of the greater Middle East, and the adoption of the 'pivot-to-Asia' policy in the early years of his

15 Tarik Oguzlu, "Turkey and the European Union: Europeanization without membership," Turkish Studies 13, no. 2 (2012): $229-43$.

${ }^{16}$ Tarik Oguzlu and Mustafa Kibaroglu, "Turkey and the US in the $21^{\text {st }}$ Century: Friends or Foes?," Korean Journal of Defense Analysis 20, no. 4 (2008): 357-72.

17 Ziya Onis, "Turkey and the Arab Spring: Between Ethics and Self-Interest," Insight Turkey 14, no. 3 (2012): 1-19.

18 David Gardner, “Turkey's Foreign Policy of 'Precious Loneliness'," Financial Times, November 16, 2015, https://www. ft.com/content/69662b36-7752-11e5-a95a-27d368e1ddf7.

19 Andreas Krieg, "Externalizing the Burden of War: The Obama Doctrine and US Foreign Policy in the Middle East," International Affairs 92, no. 1 (2016): 97-113. 
second term, seem to have enabled regional countries like Turkey to demonstrate a growing degree of strategic autonomy in their external relations.

Likewise, Obama's 'strategic patience' and 'retrenchment' policies paved the way for China, Russia, and other non-western rising powers to increase their assertiveness and agency in foreign policies. Obama's assumption that if the US outsourced some of its security responsibilities to others, peace and stability would be more likely to arise, seems to have led many countries to conclude that the US had entered a period of terminal decline, and that a post-American world order would be constructed sooner than later. It was not a coincidence that Turkey's quest for strategic autonomy coincided with Obama's admission that he was the first American president in an emerging post-American world.

One should also note that during this time period, neither Russia nor China stood against core American interests in the Middle East and East Asia. Russia was put under US-led economic sanctions in the wake of its annexation of Crimea in 2014, and its support of Russian speaking separatist forces in eastern Ukraine. China was trying to challenge western primacy in East Asia, while avoiding global responsibilities as much as possible. Establishing the Asian Infrastructure and Investment Bank, setting in motion the One Belt One Road initiative, investing in anti-access area denial military capabilities, tying neighboring countries to Beijing through a web of economic cooperation initiatives, and disputing the legal status of reefs and islets in East and South China Seas are all examples of China's efforts to become the regional hegemon in East Asia. ${ }^{20}$

When American willingness to outsource security responsibilities to regional players combined with the relative absence of non-western global actors in the Middle Eastern theater, it was not difficult for Turkish rulers to clamor for regional leadership and aggressively pursue an order-creator role to the south.

\section{Realism Redux in the Emerging Multipolar World Order, 2015-2018}

As Turkey has been disappointed by the turn of developments in the Middle East from early 2015 onward, particularly in Syria, a sense of realism seems to have come back to Turkish foreign policy. The liberal optimism that appears to have inspire Turkey's increasing selfconfidence during Obama's presidency has gradually come to an end with three systemic developments. First, Trump, during the election campaign and during his first year in office, severely accused the Obama administration of deconstructing American leadership in Middle East. To Trump, Obama's pursuit of 'leading from behind' and 'outsourcing responsibility to regional actors' policies seems to have emboldened other players to dictate developments in the region. The Trump administration wants to play a more assertive role in Middle East, particularly in the context of international efforts to defeat ISIS, to support Syrian Democratic Forces-PYD in northern Syria as a strategic ally, and to help contain Russia and Iran's influence in the region. Turkey felt disappointed by the Obama administration's reluctance to offer overwhelming support to anti-Assad opposition groups in Syria. But the Trump administration's policy of continuing military aid to the PKK-affiliated Kurdish groups in northern Syria in the name of defeating the Islamic State, and containing Russian and Iranian influence in the region, has aggravated Turkey's security concerns. ${ }^{21}$ Many Turks

${ }^{20}$ Liu Feng, "China's Security Strategy towards East Asia," The Chinese Journal of International Politics 9, no. 2 (2016): 151-79, https://doi.org/10.1093/cjip/pow003.

${ }^{21}$ Ahmet K. Han and Behlül Özkan, "Turkey and United States in Syria: Allies, Frenemies, or Worse?," (On Turkey series, 
now see the US as the primary security threat to Turkey. Anti-Americanism has never been so high in Turkey, a longtime member of NATO since $1952 .{ }^{22}$

Second, Russia's military involvement in Syria in late 2015 appears to have radically changed the security and political dynamics on the ground, most importantly by helping the Assad regime reclaim some lost territories and gain international legitimacy. Third, Iran's efforts to help bolster the Assad regime have gained a new impetus following the recapture of the territory held by ISIS, particularly Mosul in Iraq, and Raqqa in Syria. Faced with the Trump administration's determination to scrap the nuclear treaty signed with Iran in summer 2015, and further isolate the Iranian regime, Tehran appears to have decided to pursue a more assertive and bolder regional policy than before in order to preempt American belligerence.

When these systemic effects combined with Turkey's growing exposure to PKK-PYD affiliated terrorism threats since 2015, it appears Turkish decision makers concluded that Turkey requires a new foreign policy mentality. In recent years, Turkey has not proven to be an influential actor in shaping the developments in its neighborhood. Some have even underlined the misery of Turkey by pointing out that the 'zero problems with neighbors' policy has now been replaced with the unwanted outcome, 'zero neighbors without problems'.

Due to the worsening security environment in the region, and its negative consequences on Turkey's internal peace and stability, Turkish decision makers have now opted for a new foreign policy line that increasingly demonstrates the primacy of conventional security concerns. Following the replacement of Ahmet Davutoglu by Binali Yildirim as Turkey's prime Minister in the spring of 2016, Turkey appears to have embarked on a realist foreign policy stance; its operational logic is to decrease the number of Turkey's enemies while increasing the number of its friends. The ideological zeal of helping transform the region to reflect Turkey's domestic values (under the stewardship of AK Party governments), has gradually given way to the more realist concern of preserving Turkey's territorial integrity and societal cohesion amidst the re-emergence of traditional security concerns to the south.

Combined with the ominous coup attempt of July 2016, Turkey's rulers have now put security concerns at the center of their domestic and foreign policies. The practice of dealing with traditional security problems through further politicization seems to have now been replaced by practicing resecuritization at multiple fronts. The revival of the infamous siege mentality has now engendered the 'security first' approach in Turkey's external relations. The question of whether a country is friend or foe to Turkey is now being increasingly answered on the basis of that country's support, or lack thereof, to Turkey's war against multiple sources of terrorism threats (i.e., PKK/PYD forces in Syria, the FETO terror organization at home and abroad, the Islamic State, and the leftist DHKP-C terrorist organization).

In light of deteriorating relations with the United States and diminishing prospects of Turkey's accession to the European Union, Turkish decision makers have lately invested much more capital and energy into improving relations with Russia and China. The debates on whether Turkey should join the Russia-led Eurasian Economic Union or the China-led Shanghai Cooperation Organization have intensified in recent years. The more Turkey felt excluded from the western international community, the closer it came to non-western rising powers.

September 15, 2017, German Marshall Fund of the United States, Washington DC), http://www.gmfus.org/publications/turkey-andunited-states-syria-allies-frenemies-or-worse.

${ }^{22}$ A survey conducted in 2017 by Kadir Has University has found that the US is the biggest threat with the percentage of 66,5. For more information about the survey: http://www.khas.edu.tr/news/1588. 
Russia's military involvement in the Syrian theater in September 2015, combined with America's refusal to convincingly buttress anti-regime forces, seems to have produced two specific outcomes in Turkey's security thinking. First, Turkish rulers have realized that Turkey's ability to help shape the course of developments in the Middle East has now significantly weakened in the presence of Russian military elements. Russian and Iranian support to Assad seems to have bolstered the ability of the Damascus regime to remain in power. Second, closer relations with Russia are now seen as vital to Turkey's ability to defeat the PKK-affiliated Kurdish groups in northern Syria. Without the tacit Russian approval, Turkey's military incursions of northern Syria, first in August 2016 and then in January 2018, might not have been possible. Turkey's efforts, in close cooperation with Russia and Iran, to contribute to the solution of the Syrian crisis through diplomatic means (the so-called Astana and Sochi processes), have also intensified following Russian's more decisive penetration into Syria.

Improving relations with Russia has become important in terms of Turkey's worsening relations with western powers in the wake of the July 2016 coup attempt. The eroding trust of western powers seems to have brought Turkey much closer to Russia. It is now believed in Ankara that western powers are not happy to see Turkey become a regional heavyweight that continuously criticizes the legitimacy of western policies in Middle East.

It is against this background that Turkish rulers increasingly voice that the world is bigger than five, and that Turkey's efforts to develop cordial and pragmatic relations with non-western rising powers should proceed as quickly as possible. Signing up to Asian Infrastructure and Investment Bank, showing interest in developing joint projects with China (within the framework of the One Belt One Road initiative), contributing to global and regional governance initiatives (such MIKTA and MINT), buying a S-400 missile defense system from Russia, and establishing military bases in faraway regions (such as Qatar and Somalia) are all noteworthy examples of these efforts.

Of particular importance are Turkey's increased efforts to deal with the worsening security environment in its own region through unilateral initiatives. Turkey's organization of two military operations in northern Syria, the Euphrates Shield and the Olive Branch, testifies not only to Turkey's diminishing trust in its western allies, but also to its growing predisposition to act unilaterally when the pushed.

\section{Conclusion}

This article argues that the structure of the international order and the way Turkish foreign policy has unfolded over the last fifteen years are closely interrelated. As the international system has evolved from a unipolar order in which the US (in cooperation with its European allies), provided the main public goods in a hegemonic fashion, into a post-unipolar era, Turkey has accelerated its efforts to pursue a more multi-dimensional and multi-directional foreign approach. ${ }^{23}$ The gradual erosion in the relative weight of western powers in international politics, and the concomitant rise in the influence of non-western powers, appears to have increased Turkey's maneuvering capability and bargaining power in its foreign policy.

As Turkey moved away from a predominantly pro-western foreign policy understanding to a more strategic autonomy, analysts have increasingly asked whether this has signified a

\footnotetext{
${ }^{23}$ Tarık Oguzlu and Emel Parlar Dal, "Decoding Turkey's Rise: An Introduction,” Turkish Studies 14, no. 4 (2013): 617-36.
} 
shift of axis in Turkish foreign policy. ${ }^{24} \mathrm{~A}$ more accurate description would be that as Turkey has become more powerful and as the world has moved much closer to a post-American order, Turkey has begun to adopt bolder and more assertive foreign policy stances. Turkey's economic power, as relative to neighboring countries, has grown spectacularly. The threefold increase in Turkey's GDP over the last fifteen years has allowed Turkey to increase investments in its military-industry, and adopt an autonomous course of action in its foreign policy.

Despite Turkey still valuing its NATO membership and its prospective membership in the European Union, in recent years Turkey has had an increasing tendency to come closer to Russia and China, and become more active than ever in Middle East. Whether this is called 'Middle Easternization', 'Eurasianism', or 'strategic autonomy', one can safely argue that Turkey no longer views its external environment from a predominantly pro-western perspective.

The weakening of westernism in Turkish foreign policy cannot be solely attributed to the gradual erosion of western primacy in global politics. In recent years, Turkey has had more anxiety concerning security, and American policies in the Middle East over the last fifteen years have played the key role. The image of the West as Turkey's ultimate security provider has eroded, as many US-led policies in the post 9/11 Middle East seem to have endangered Turkey's sense of security.

The growing appeal of the 'Beijing model', as well as resurgent nationalism as manifested in Putin's Russia, has hollowed out the normative underpinnings of the US-led liberal international order. Turkey seems to be one of those 'swing' states that has shown a growing willingness to accommodate non-western powers in international politics.

One should also admit that both Russia and China appear to approach Turkey from an instrumental perspective; driving wedges among NATO allies, in this case particularly between Turkey and the United States, would likely increase their bargaining power with the United States. Worth noting is that neither Russia nor China is willing to admit Turkey to the international organizations that they lead as full members.

This suggests that Turkey comes closer to these countries and other non-western international organizations in its efforts to help soft-balance western powers. Turkey has not proven that it is a revolutionary state aiming at radically overhauling liberal international order. Provided that the liberal international order would more convincingly reflect the existing balance of power in today's world, Turkey would likely opt for the current liberal order.

${ }^{24}$ Ekrem T. Başer, "Shift-of-axis in Turkish Foreign Policy: Turkish National Role Conceptions Before and During AKP Rule," Turkish Studies 16, no. 3 (2015): 291-309. 


\section{Bibliography}

Acharya, Amitav. "The Future of Global Governance: Fragmentation May Be Inevitable and Creative." Global Governance 22 (2016): 453-60.

Aras, Bülent, and Rabia Karakaya Polat. "From Conflict to Cooperation: Desecuritization of Turkey's Relations with Syria and Iran.” Security Dialogue 39, no. 5 (2008): 495-515.

Başer, Ekrem T. "Shift-of-axis in Turkish Foreign Policy: Turkish National Role Conceptions Before and During AKP Rule.” Turkish Studies 16, no. 3 (2015): 291-309.

Boyle, Michael J. “The Coming Illiberal Order.” Survival 58, no. 2 (2016): 35-66.

Duncombe, Constance, and Tim Dunne. “After Liberal World Order.” International Affairs 94, no. 1 (2018): 25 -42.

Feng, Liu. "China's Security Strategy towards East Asia.” The Chinese Journal of International Politics 9, no. 2 (2016): 151-79.

Gardner, David. “Turkey’s Foreign Policy of 'Precious Loneliness.” Financial Times, November 16, 2015. https:// www.ft.com/content/69662b36-7752-11e5-a95a-27d368e1ddf7.

Godement, François. "Expanded Ambitions, Shrinking Achievements: How China sees the global order." Policy Brief, March 2017, European Council on Foreign Relations, London, UK. http://www.ecfr.eu/publications/ summary/expanded_ambitions_shrinking_achievements_how_china_sees_the_global_order.

Han, Ahmet K., and Behlül Özkan. "Turkey and United States in Syria: Allies, Frenemies, or Worse?” On Turkey series, September 15, 2017, German Marshall Fund of the United States, Washington DC. http://www.gmfus. org/publications/turkey-and-united-states-syria-allies-frenemies-or-worse.

Ikenberry, G. John. "The Plot Against American Foreign Policy Can the Liberal Order Survive?" Foreign Affairs 96 (May/June 2017): 2-9.

Krieg, Andreas. "Externalizing the Burden Of War: The Obama Doctrine and US foreign policy in the Middle East." International Affairs 92, no. 1 (2016): 97-113.

Lobell, Steven E., Norin M. Ripsman, and Jeffrey W. Taliaferro, eds. Neoclasical Realism, the State and, and Foreign Policy. Cambridge: Cambridge University Press, 2009.

Lukin, Alexander. "Russia in a Post-Bipolar World.” Survival 58, no. 1 (2016): 91-112.

Oguzlu, Tarik. "Turkey and the European Union: Europeanization without membership.” Turkish Studies 13, no.2 (2012): 229-43.

. "Turkey and Europeanization of Foreign Policy." Political Science Quarterly 125, no. 4 (2010-2011): $657-83$.

Oguzlu, Tarik, and Emel Parlar Dal. "Decoding Turkey’s Rise: An Introduction.” Turkish Studies 14, no. 4 (2013): 617-36.

Oguzlu, Tarik, and Mustafa Kibaroglu. "Turkey and the US in the $21^{\text {st }}$ Century: Friends or Foes?" Korean Journal of Defense Analysis 20, no. 4 (2008): 357-72.

Onis, Ziya. "Turkey and the Arab Spring: Between Ethics and Self-Interest.” Insight Turkey 14, no. 3 (2012): 1-19.

Öniş, Ziya, and Şuhnaz Yılmaz. "Turkey and Russia in a Shifting Global Order: Cooperation, conflict and asymmetric interdependence in a turbulent region.” Third World Quarterly 37, no. 1 (2016): 71-95.

Posen, Barry R. "The Rise of Illiberal Hegemony.” Foreign Affairs, February 2018. http://www.foreignaffairs.com/ articles/2018-02-13/rise-illiberal-hegemony.

Wilkins, Thomas S. “'Alignment', not 'Alliance'- The Shifting Paradigm of International Security Cooperation: Toward a Conceptual Taxonomy of Alignment.” Review of International Studies 38, no. 1 (2012): 53-76. 